l'objet d'une communication au colloque de Lama-Kara sur la tradition orale, en Septembre 1967, publiée dans les cahiers du CERK (Centre d'études et de Recherches de Kara, Piya par Lama-Kara, Togo). Depuis i 968 , en collaboration avec des collègues sociologues et géographes, il poursuit l'étude socio-économique des populations du groupe Adja-Fon vivant dans le Sud-Est du Togo: incidences de la traite sur l'organisation socio-politique aux $18^{\mathrm{e}}$ et $19^{\mathrm{e}}$ siècles, rapports entre l'homme et la terre, activités économiques des femmes.

Mme M. C. Le Cocq, géographe, a étudié en $19^{6} 7$, dans le Sud-Est (région de peuplement Ouatchi, Mina dominant), dans une zône de très forte densité démographique, les causes des migrations au sein même de la région. Cette recherche sur le surpeuplement, abordée par le biais d'une étude de terroir, a fait l'objet d'un rapport en cours de publication.

$\mathrm{Cl}$. Sauvaget, géographe, étudie en pays Kabrè, depuis 1968 , les correspondances entre une densité de population très élevée et le système agraire, par le biais d'une étude de terroir qui sera complétée par une enquête régionale; ce travail a fait l'objet d'un rapport préliminaire multigraphié; un texte regroupant les résultats de la première phase des recherches est en cours de rédaction.

A. Carbonnier, sociologue, arrivé à la fin de 1968, effectue dans le cadre de l'étude interdisciplinaire sur les structures foncières et les structures agraires de la région du Sud-Est, une monographie foncière dans une communauté villageoise, Sê (Shai), située à la limite Nord-Est de la région habitée par des populations Ouatchi et Mina.

B. Antheaume, géographe, arrivé à la fin de 1968 , après des tournées interdisciplinaires dans la région du Sud-Est, a commencé une étude monographique de terroir dans la basse vallée du Mono, région qui contraste par le milieu naturel et la faible densité de population avec celle étudiée par Mme Le Cocq.

A. Hauser, arrivé à la fin de I968, poursuit au Togo ses recherches de sociologie industrielle et de psychosociologie du travail commencées en I95 r en Afrique équatoriale et continuées à partir de 1953 en Afrique occidentale. Il achève l'étude d'un échantillon de 350 travailleurs des industries extractives (phosphate) et enquêtera ensuite dans les industries manufacturières (textiles). La connaissance de l'histoire professionnelle des travailleurs permet d'établir un certain nombre de données sur l'emploi. Un questionnaire d'attitudes porte sur l'intégration à la vie industrielle, les aspirations des travailleurs et divers problèmes en relation avec la vie professionnelle; le matériau obtenu ainsi est soumis à un traitement fondé sur une méthode statistique récente, l'analyse factorielle des correspondances.

\title{
Création d'une section de linguistique à l'Institut National Tchadien pour les Sciences Humaines de Fort-Lamy (Tchad)
}

A LA demande du Ministère de l'Éducation Nationale et de la Culture du Tchad, le directeur de l'I.N.T.S.H. (Prof. Dr. J.-P. Lebeuf) a créé une section linguistique qui prendra place à côté des sections déjà existantes de: paléontologie, préhistoire, protohistoire, histoire, ethnologie, anthropologie physique et biologie humaine, géographie. La responsabilité de cette nouvelle section a été confiée à $M$. Jean-Pierre Caprile, chercheur de l'équipe de Recherche $\mathrm{n}^{\circ} 74$ du C.N.R.S., Attaché de recherche au C.N.R.S., dont les études portent sur le groupe des langues dites 'sara' (ou bonga-bagirmi) et, plus particulièrement sur l'une d'entre elles, le mbay.

La nouvelle section se propose d'être: (a) un centre de documentation mettant à la disposition des chercheurs une bibliothèque spécialisée et des archives sonores, et tenant à jour la partie linguistique de la Bibliographie du Tchad (Sciences Humaines) éditée par l'I.N.T.S.H., (b) un centre de recherche pour la description et la comparaison des langues du Tchad, $(c)$ un lieu de rencontre des linguistes qui travaillent sur les langues tchadiennes et, éventuellement, un moyen de collaboration interdisciplinaire pouvant amener à des applications pédagogiques. 
L'établissement d'une carte linguistique du Tchad est la première tâche confiée à la section linguistique. Cette carte figurera dans l'Atlas général tchadien dont la réalisation a été entreprise par la section de géographie de l'I.N.T.S.H. dirigée par M. le Doyen Jean Cabot.

\section{The Nigerian Geographical Association: 14th Annual Conference, 1969}

THE Conference, which took as its general theme 'Geography for development', was planned and arranged by the Department of Geography at Ahmadu Bello University. The Presidential Address, on the subject 'The role of geographers in national reconstruction', was given by Professor R. A. A kinola, and the following open lectures were delivered: 'Industrialization in West Africa: the need for sub-regional groupings within a regionally integrated economic community' (Professor K. M. Barbour); 'Migration policy and regional development in Nigeria' (Professor A. L. Mabogunje); 'Upper air and surface weather' (Dr. P. N. Hore); 'Travel behaviour patterns and economic development in Nigeria ' (Dr. G. J. Afolabi Ojo). The Conference had a dual emphasis on the educational role of the subject in Nigeria and on its practical applications in such fields as regional planning and land resource assessment.

\section{African Studies at the National Chengchi University, Taiwan}

THE Graduate Institute of the National Chengchi University (Mushan, Taipei, Taiwan) is developing its Program of African Studies. In addition to the course on Contemporary Africa given since 1964 by the Director Dr. Tu Kwang-hsun, Dr. F. M. Bourret (of the Sacred Heart, Taipei) is giving a course on Political Development in West Africa and Mr. Chin, who has returned from graduate studies and field-work in London and Ghana, is teaching on the Modern History of Africa.

\section{Rhodes University, Grahamstown: Institute of Social and Economic Research}

RESEARCH projects being undertaken and prepared for publication by members of the Department of African Studies include the following: The decision-making process in a rural community: Lesotho (J. A. G. Perry); A study of a Chopi community in Inharrine, Moçambique (D. G. Webster); A community settlement scheme in João Bello, Moçambique (Miss K. Mack); Social and economic change in a Swazi rutal community (A. N. Ross). Professor Philip Mayer of the University of Durham, formerly head of the Department of African Studies, has been awarded the University Fellowship for 1970 and is continuing his researches among the Cape Nguni people.

\section{Project for a Centre of New Religious Movements at the University of Lancaster (England)}

A PRELIMINARY announcement is made of the plan recently adopted by the University of Lancaster (England) for the establishment of a Centre for New Religious Movements during the next university quinquennium, 1972-7. This will encourage interdisciplinary and comparative study of the modern religious movements familiar to Africanists, and also of their equivalents in the Americas, Australia, Oceania, and parts of Asia. The Centre will be connected with the Department of Religious Studies under Professor Ninian Smart but also with other relevant departments, and will be under the direction of Dr. H. W. Turner. It is aimed to provide world documentation in this field, to offer an M.A. by course work, research facilities for higher degrees, and if funds permit to become the first depository 